\section{Manual de Medicina Intensiva}

\section{Handbook of Intensive Care Medicine}

Editor: Max Andresen $\mathrm{H}$. ISBN: 978-956-220-417-0 (465 págs.)

Editorial Mediterráneo Ltda., 2019.

Santiago de Chile.

¿Qué es un "Manual” y qué lo hace distinto a un texto de estudios? El Diccionario de la Lengua Española asigna catorce significados al término "Manual" y en el caso que comentaré creo que el que mejor aplica es: "Libro en que se compendia lo más sustancial de una materia".

Eso es, precisamente, este Manual de Medicina Intensiva que desde su primera edición, en el año 2010, ha tenido un éxito notable y, según me han informado, es el texto de estudios preferido por los becados que se forman en medicina intensiva y los profesionales que se dedican a esta especialidad. Tres años después tuvo una segunda edición y en la actualidad se presenta su tercera edición, con treinta y nueve capítulos que se inician apropiadamente con la Estructura, función y gestión en cuidados intensivos y terminan con doctos consejos sobre Decisiones al final de la vida.

Participaron en este Manual sesenta y dos autores y coautores de múltiples especialidades médicas y quirúrgicas. Treinta y ocho $(61 \%)$ son académicos de la Universidad Católica de Chile, catorce (22\%) lo son de la Universidad de Chile y los demás provienen de otra universidad, de clínicas privadas y servicios de salud. Además de médicos clínicos, contribuyeron salubristas e investigadores biomédicos, kinesiólogos, químicas farmacéuticas, enfermeros, becados y una doctora en filosofía. Esta amplia gama de profesiones e inquietudes académicas refleja el carácter multidisciplinario de la medicina intensiva, una especialidad médica joven, con poco más de treinta años de historia.

En las últimas décadas del siglo XX el progreso de las ciencias y la tecnología ha motivado la aparición de especialidades muy importantes: genómica, genética clínica, medicina molecular, medicina personalizada, informática médica y otras. Creo que ninguna tiene la trascendencia clínica alcanzada por la medicina intensiva, que ha conseguido una reducción de la mortalidad en situaciones críticas recuperables, convirtiéndose en un atractivo para médicos jóvenes y consiguiendo el reconocimiento de los pacientes y el público general. No debemos dejar de considerar el rol clave de las unidades de medicina intensiva para la selección de los pacientes que ameritan recibir un trasplante de órgano y su atención postoperatoria, así como la selección de posibles donantes de órganos, aplicando un protocolo técnico y ético que tiene validez universal en la medicina de hoy.

Recibí mi título de médico cirujano hace cincuenta y nueve años y mi primera actividad profesional fue cumplir una beca residencia de tres años en medicina interna. Recuerdo que con mis colegas sufrimos a veces el desaliento de no poder solucionar situaciones clínicas extremas que hoy son manejadas exitosamente en unidades de pacientes críticos. Este Manual revisa esas situaciones, refuerza los conocimientos que deben guiar en la toma de decisiones y la ejecución de medidas apropiadas para resolverlas. El Manual actualiza también conceptos fisiopatológicos en temas como sepsis, sistema inmune, perfusión regional y sistémica, farmacocinética y el uso adecuado de antibióticos, eludiendo la forma frecuente de agrupar una colección de guías de diagnóstico y protocolos de tratamiento.

Sería inapropiado de mi parte opinar sobre el contenido técnico de la mayoría de las materias tratadas en este Manual, porque están fuera de mi alcance. Carezco de experiencia en el manejo de ventilación mecánica, arritmias complejas, reanimación cardiocerebral, etc. Me tranquiliza confiar en que quienes presentan estas materias están hablando un lenguaje que los lectores comprenden y pueden utilizar en la práctica de la medicina intensiva.

En cambio, me siento autorizado para evaluar requerimientos generales del tema, como la importancia de una adecuada relación entre médicos, pacientes y sus familiares, particularmente en situaciones críticas que pueden prolongarse varios días, con características y reacciones variables en plazos muy breves, de horas o minutos. El Manual identifica y analiza con claridad meridiana los aspectos que le competen, como el paciente y su entorno, la justificación del ingreso a la unidad y la permanencia en ella, las relaciones con las familias, la información clínica adecuada para cada paciente y su familia, la supervisión del personal en las unidades, la cohesión del equipo de salud 
y su responsabilidad en la formación de futuros especialistas.

La revista New England Journal of Medicine del 11 de julio de este año publicó un interesante análisis de la Desconfianza en la Ciencia, calificándola como una amenaza para la relación médico-paciente, dado que la confianza es la base de toda relación entre el paciente y el sistema de salud. La evolución de la atención médica ha provocado una merma de las relaciones directas y estables entre el paciente y un determinado médico, para cambiarla por una relación entre los pacientes y los protocolos de las instituciones en que se atienden. Las Unidades de Medicina Intensiva adquirieron una importancia fundamental para ganar la confianza de los pacientes. Si se cometen errores o se crea desconfianza en sus procedimientos, trasladan de inmediato esta desconfianza a toda la institución que representan.

Quise formarme una opinión sobre qué piensan pacientes que han estado hospitalizados en unidades de cuidados intensivos. Recurrí a cinco personas cuyo juicio me merece respeto. Fueron tres damas y dos varones. Dos son abogados, una es profesora de farmacología, uno psicólogo laboral y una pediatra. A todos les hice dos preguntas: ¿Qué fue lo más positivo que recuerda de su hospitalización en UTI? y ¿Qué recuerda como lo más negativo de ella? Los cinco calificaron como lo más positivo la calidad de la atención recibida, la sensación de seguridad y protección. Consideraron lo más negativo el aislamiento de la familia y al menos una persona criticó el ruido ambiental por conversaciones del personal en alta voz durante las noches. Si esta pequeña encuesta reflejara las opiniones de muchos otros pacientes que han vivido circunstancias similares, indicaría para mí que los equipos que atienden las unidades de pacientes críticos están siguiendo apropiada- mente las recomendaciones que les da este Manual y con ello sus unidades son pilares que sustentan la confianza de los pacientes en las instituciones respectivas y les dan un sello positivo, lo que es mucho más complejo que valorar solamente la autoridad propia de la experiencia, la sabiduría científica y la capacidad técnica de los médicos y el equipo de salud.

En cuanto a las características formales del Manual, destaco la armonía de la sintaxis y el estilo de la escritura médica científica, algo difícil de conseguir en un texto con multi autoría. La calidad de la impresión por la Editorial Mediterráneo es encomiable: elección del papel, tamaño de letras, uso adecuado de colores, tablas e imágenes claras, separación de los capítulos. Una sugerencia para los autores de una futura edición es que agreguen un glosario que permita al lector ubicar rápidamente los términos que le interesan, en todos los lugares del libro en que se los menciona.

En síntesis, este Manual es un libro excelente que ocupa un lugar privilegiado para la formación y la práctica de la medicina intensiva. Es una iniciativa que contribuye al prestigio de la medicina nacional y sus autores y el editor merecen las más cálidas felicitaciones por ello.

\section{Dr. Humberto Reyes B. ${ }^{1}$ \\ ${ }^{1}$ Profesor Emérito, Universidad de Chile. Editor Emérito, Revista Médica de Chile. Miembro de Número, Academia Chilena de Medicina.}

Potenciales conflictos de intereses: el Editor del Manual y el autor de este comentario hemos tenido una prolongada relación laboral en la Revista Médica de Chile. 